\title{
On the 'Pre-History of the Panoptic Sort': Mobility in Market Research.
}

\section{Adam Arvidsson1}

\begin{abstract}
This article reviews the history of market research to argue that that discipline has seen a paradigm shift during the second half of the 20th century. Originally market research developed as an integral element to the society-wide capitalist control revolution. Its aim was to contain the complexity of an increasingly mobile consumer demand in a number of pre-established categories. Since the 1950s however market researchers have developed a series of techniques to observe and make use of consumer mobility. The emergence of these new techniques was coupled to a different conception of the role of marketing. Its role was no longer understood primarily as that of disciplining consumer demand, but rather as that of observing and utilizing ideas and innovations that consumer's themselves produced. This paradigm shift from 'containment' to 'control' drove the development the statistical techniques and theoretical conceptions of consumers that are now employed in the commercial surveillance of on and off-line mobility. Through ubiquitous surveillance contemporary capitalism aims at including virtually all of social life into its valorization process. The conclusion considers the possible contradictions that this might produce.
\end{abstract}

The internet research company Redsheriff builds its business on a hidden JavaScript that loads on to your browser when you visit one of its affiliated sites (and it is very likely that you will since most major commercial sites use Redsheriff. In Australia, the company claims to cover $86 \%$ of the 'internet population' 2 ). The script records and reports your activities online: which sites you visit, what files you download, what information you supply. Building on this data, Redsheriff can tell its clients a lot about their customers, what sites they tend to visit, what their online interests are and how they move about in cyberspace. This way, your movement in cyberspace comes to produce the very informational commodity that Redsheriff sells, or at least the raw material from which it is extracted.

Redsheriff is only one of many internet tracking companies. This sector has seen an exceptional growth and consolidation with the commercialization of the internet (Campbell and Carlson, 2002). Companies like DoubleClick, Bluestreak and MatchLogic all use cookies to track your movements across their affiliated sites. Redsheriff is more advanced - or intrusive - in that its technology keeps track of all of you online movements, not just on its affiliated sites. They all

\footnotetext{
${ }^{1}$ Department of Film and Media Studies, University of Copenhagen, Denmark.mailto:arvidsson@ hum.ku.dk

${ }^{2}$ Redsheriff website: http://www.redsheriff.com
} 
build on a business model where the information sold is not primarily derived from generating data through surveys or interviews (some of them might do this too), but from processing (or 'mining'), packaging and commodifying the vast amounts of data that we all generate in our everyday online life. As Redsheriff puts it in their promotional material, "Gathering data is no longer a problem for business, there's plenty of that for any one who wants to look for it. The problem is sorting it and finding the right information" (ibid.).

This kind of 'mining business' is not exclusive to the internet. Through credit card records, mailing lists, customer benefit programs and barcode scans our flaneuring life off-line also generates its virtual double in the form of a data trail to be processed and commodified. Arbitron's 'Scarborough' service sells profiles generated from "more than 295 major categories of consumer, media and retail behaviour in your market"', Doubleclick's 'Abacus' uses "actual buying behaviour from 90 million households"4. As consumers, mobile and supposedly selfreliant, we are subject to a virtually ever-present 'panoptic sort'; a surveillant gaze that expands far beyond the walls of the prisons, factories and hospitals and schools where, according to Foucault (1977) the panoptic model first developed (Gandy, 1993; cf. Boyne, 2000; Camp, 1999; Elmer, 2003; Haggerty and Ericson, 2000). The physical, social and cultural mobility of social life, the moving about between environments and activities that has become a key characteristic of post-modern life, has also become a source of value to be realised on the market for commodified information.

Gathering and commodifying information has been a central to the economics of the culture industry ever since the late $19^{\text {th }}$ century and the establishment of a market for advertising and, consequently, for audiences. When selling and purchasing 'eyeballs', information is central to the value of the commodity traded. As Smythe's (1981) and Jhally's (1987) work on the 'audience commodity' shows, the audience has scarcely any value if it can not be defined in some way (in terms of demographic make-up or at least in terms of size). Conversely, the more precise the definition, the greater the value. Indeed, information is a crucial resource for advertisers in their (not always successful) attempts to convert the 'watching time' purchased from broadcasters into actual purchasing power (which is what they themselves claim to sell on to their clients). Some kind of information gathering is thus crucial if media companies want to attract advertising sponsorship.

While the dynamic that Smythe and Jhally describe is similar to that of today's panoptic sort, information is gathered from the activities of consumers and sold on to advertisers- there are two fundamental differences. First, in Smythe's and Jhally's models information gathering was a situated activity. Companies like Nielsen built their business on measuring people's activities in a particular setting: in their role as television audiences, in front of the set, in the living room 5 . Today, information gathering is virtually (or potentially) ubiquitous: any kind of media or market activity can become 'raw material' for the production of an information commodity. Life itself

\footnotetext{
3 Arbitron 'Scarborough' website: http://www.arbitron.com/advertisers/scarcat.htm

${ }^{4}$ Doubleclick 'Abacus' website:

http://www.doubleclick.com/us/products/direct marketing/abacus catalog alliance/

${ }^{5}$ Portable peoplemeters that measure people's watching habits as they move about outside the home have only just been launched, see: http://www.arbitron.com/portable people meters/home.htm
} 
comes to generate value. Living in a commercialized and surveilled environment also entails producing a data double that enters into the circulation of the capitalist economy as raw material for information commodities.

A second important difference is that the techniques described by Smythe and Jhally were primarily directed at placing the audience of a particular media product within a particular and relatively stable category. For example, the value of daytime radio serials derived from reliable information indicating that its audience was mainly made up of working to middle-class housewives. The knowledge interest here consisted in classifying the audience, 'containing' it within particular pre-established categories, with relatively fixed notions of taste, habits and preferences. Today, however, buyers of information are also, or even predominantly interested in the movements of consumers. It is in their surveilled mobility between stores, sites and lifestyles that consumers generate information that can be valorized. Neither do the techniques that are employed presuppose any a priori categories into which consumers are to be sorted. Rather such profiles are generated a posteriori through clustering and other forms of inductive methods.

Technical means that enable this kind of ubiquitous information gathering are relatively new. They are the offspring of the proliferation of computerized information systems and communication technologies during the last 20 years or so. An interest in mobility, however, goes further back. If sociologists have just recently begun to take mobility seriously (Urry, 2000) market researchers have taken an interest in models that could describe and 'capture' an increasingly mobile consumer society already in the late 1950s. These research techniques paved the way for today's 'data mining' services by developing the statistical clustering techniques employed, and by establishing new ways of thinking about consumer behaviour. In this article I will look at what could be called the 'pre-history' of the panoptic sort, surveying the development of an interest in mobility in within market research from the 1920s and onwards. The conclusion suggests how the development within market research that I describe can be understood as symptomatic of an emerging contradiction within informational capitalism.

\section{Mobility and Containment}

In the Middle Ages, Simmel writes, "a person was a member bound to a community or an estate, to a feudal association or a guild" and "[h]is personality was merged with real or local interest groups". This located, or situated, character of life was disrupted by the impact of money and commodity culture which "left the personality to itself and gave it an incomparable mental and physical freedom of movement" (Simmel, 1896[2000]: 244). To associate money and commodity culture with a heightened mobility and mutability of personal and social identity had since become a central theme in social theory. As Simmel remarked, this mobility is both 'physical and mental'. Automobiles, mass transport and the tourism industry permit an unprecedented mobility across physical space (Urry, 2000). Consumer goods permit the mobility between different identities and forms of self-presentation. Thus social mobility is marked by new patterns of acquisition and possession (Bourdieu, 1984; Skeggs, 2003). 
Other kinds of transformations, from adolescence to adulthood, from conformity to political commitment, from gay to straight or simply from one life-style to another, are marked, or in some cases partially achieved through a transformation in the set of commodities used or possessed (Miranda, 1998). A diversified and multifaceted media environment permits easy mobility across channels and 'content space' producing and 'evasive' or 'unmanageable' consumer whose 'attention' becomes a scarce resource (Ang, 1996; Gabriel and Lang, 1995; Davenport and Beck, 2000). With the mediatization of social life, these different realms of mobility tend to overlap, transforming the life-world itself into a performative realm where spatial, material and media resources can be mobilized to make and unmake particular forms of selfpresentation, often of a local or temporary nature (Cova, 1997; Harvey, 1990; Maffesoli, 1996; Meyrowitz, 1984; cf. Abercrombie and Longhurst, 1998).

The emergence of such a performative attitude has worked to destabilize established social borders. Indeed, looking at the historical scholarship on the rise of consumer capitalism it seems that, apart from a certain disgust at the vulgar attempts to imitate class and style on the part of nouveaux riches, it has been this mobility of identity and the concomitant blurring of social boundaries that has seemed most threatening to conservative observers. Richard Sennett (1977), to take one example, describes how dress code laws of 17th century France took form as an attempt to limit and contain the new possibilities for transgressive, public self-presentation that an emerging mass production made possible. People would appear in the wrong place dressed in the wrong way, and this was perceived as deeply challenging. Nineteenth-century department stores are another example of how the physical, mediatic and material realms merge to permit a destabilizing mobility of identity (Bowlby, 1985; Miller, 1981).

Market research developed as part of a wide attempt to control, and originally, contain, this enhanced mobility of identity. When serious research into consumer tastes, habits and buying patterns took off in the years following World War I, the main enemy was the perceived mutability and 'irrationality' of existing consumer patterns. Most early market researchers, like their marketing colleagues in general, were steeped in the then dominant paradigm of 'scientific management' and they aimed at a 'Taylorization' or even 'engineering', to use Elmo Calkins influential term, of consumer demand (Calkins and Holden, 1905). Like in he case of the 'scientifically' managed work process, this entailed the use of market knowledge to break down consumer demand into clearly identifiable segments. These segments could then be targeted by advertising that sought to educate, rationalize and shape attitudes and behaviour. The aim was to construct particular practices and taste patterns and to tie them to particular physical or mediatic places, such as the home, the supermarket or the women's magazine.

Such 'rationalizing' or disciplinary practices were deemed particularly necessary in relation to consumer segments that were thought to be prone to irrational tastes or preferences, like recently arrived immigrants - to be Americanised through advertising and market propaganda (Ewen, 1976) - women (Scanlon, 1995) and youth (Palladino, 1996) ${ }^{6}$. The segmentation of consumer demand thus worked to contain the potential diversity of consumer practice within workable

\footnotetext{
${ }^{6}$ Straight, white men, whose consumer demand was substantial, figured very rarely in the discourse of the advertising and marketing profession (cf. Osgerby, 2001).
} 
categories. As the following will argue, these categories developed in relation to the then dominant advertising medium: the weekly (or monthly) magazine.

\section{Early market researc $h$ : The Containment Paradigm.}

Given the central role of information in the economics of advertising and the media industry, the theories and methods employed in producing information have been heavily influenced by the dominant media structure. Indeed, studies of consumer behaviour did not really come about until the establishment of mass circulating, advertising-financed weekly magazines attributed a central economic role to the commodification of audiences. Although systemic studies of the consumer market began in the US already with industrialization, early market research nurtured a rather scant interest in consumers. Rather, early studies found their main inspiration in German institutional economics, as did early academic marketing in general (Bartels, 1976, Jones and Monieson, 1990). These studies were mainly concerned with the institutional dynamics of markets and distribution systems. Research on consumer behaviour, attitudes and motivations first developed elsewhere, in the field of advertising psychology, with experimental research on the effectiveness of this new medium of persuasion, (Arvidsson, 2003, Beale, 1992, Chessel, 1995). Magazine publishers, who had sold their publications under production costs and relied heavily on advertising revenue ever since the 1890s, were the first to begin to market its readership as an 'audience of consumers'.

Originally this was done without any kind of 'scientific' backing what so ever. Based on letters to the editor or, like Ladies World, photographs the homes of subscribers, they sought to market their audience to advertisers as representative of a particular kind of consumer, usually defined in terms of social class. Thus Harpers's Bazaar was supposedly read in upper class households, Ladies Home Journal represented an audience of rational and frugal middle class housewives, and so on (Ohmann, 1996; Fox, 1984, Scanlon, 1995). In the immediate post war years however, big publishers like Curtis (True Story, Love Magazine, Ladies Home Journal) set up research departments, and a number of research consultancies, like the Eastman company, developed to service small publishers (in the case of Eastman the Christian Herald and Cosmopolitan magazine). All of these surveyed readers for data on income and demographic composition (Lockley, 1950).

In the 1930s it became common for mass circulating magazines (and for radio companies like CBS) to maintain readers' panels. Woman's Home Companion, for example launched a panel in 1935, consisting first of 250 and then expanding to 1500. Panellists were selected to represent different ages, occupations and income levels among the journal's readers, and they were asked to answer a survey on matters like family size, husband's occupation, type and size of home, furniture, equipment, gardens, domestic help, laundry methods, car ownership, income levels, interests and hobbies. While on the panel, members were frequently interviewed on topics like meal planning, food preparation, laundry fashions, household equipment, leisure time, home decoration, and child care. The CBS panel was checked in even more detail. Through so called 'pantry checks' an interviewer visited the homes of housewives on the panel over a period of several weeks to observe which brand names had appeared and disappeared (Converse, 1987: 
92; Lazarsfeld, 1938).

Much data on consumer demographics, behaviour and purchasing patterns was thus generated. However, publishers still assumed that this data could be presented as representative of a particular group of consumers, whose characteristics largely coincided with the life-world presented by the magazine itself. As the Spanish American Publishing company claimed in an ad for Cinelandia, a Motion picture magazine directed to the Latin American market: "just a glance through the magazine shows you the type to whom it is directed" (Export Advertiser, 1930). There was a general assumption that the cultural space of a magazine was a good representation of the practices and attitudes of its readers. When radio promoted the development of nationwide ratings research in the 1930s, class differences roughly coinciding with differences between magazines were reified into a standardized typology, the so called ABCD system, used to differentiate households according to income.

As we can see from the way the J. Walter Thompson Cooperation's chief researcher Paul Cherington (1924) recommended the operationalization of the ABCD system, income differences were understood to imply a lot more about lifestyles and outlook. To him the categories meant the following:

A. Homes of Substantial wealth above the average in culture that have at least one servant. The essential point, however, in this class is that the persons interviewed shall be people of intelligence and discrimination.

B. Comfortable middle class homes, personally directed by intelligent women.

C. Industrial homes of skilled mechanics, mill operators or petty trades people (no servants)

D. Homes of unskilled labourers or in foreign districts where it is difficult for American ways to penetrate.

(Cited in: Converse, 1987: 113)

There were no research data on motivations and attitudes that could substantiate such claims. Rather, the ABCD typology worked as a way of giving 'scientific' legitimacy to speculations about aspects of consumer behaviour on which there were no data available. Indeed, as the ABCD typology was sedimented in the 1930s through its deployment in the Cooperative Analysis of Broadcasting's (CAB) nationwide ratings research (which became the standard measure in the 1930s), and latter in the Nielsen ratings index (launched in 1942), it provided a convenient ground for such speculations. Indeed, in the CAB survey much was hypothesised (or, 'surmised' to use the actual expression) about the actual behaviour of each group. The relatively small share of the radio audience pertaining to group A was supposed to be explained not only by economic factors but also by "them having [...] a wide range of social interests and activities limiting time for listening [and] the fact that the average program is directed to lower income groups making them of little interest for the A group". Conversely, the C group's high index of listening was explained by 'lower educational standards' making listening the "preferable way of getting information” (Beville, 1940: 198; ff. James, 1938; cf. Bogart, 1987).

As the $\mathrm{ABCD}$ typology was sedimented as the main basis for market and audience "nose 
counting, it came to work as a convenient sorting device. It permitted market and audience researchers to place consumers (and listeners) in established categories based on data on income and/or residence. Once placed in such a category accompanying assumptions about relatively fixed motivations, attitudes and life styles made it possible to legitimately deduce further ideas about consumers. This way, the ABCD typology worked to reduce, or contain the complexity of consumer mobility into a relatively neat and simple typology that permitted a highly standardized and streamlined marketing effort. Indeed, with the ABCD typology classifications originally derived from the structure of the magazine advertising market were developed into general categories, used to contain and manage a wide diversity of consumer practices.

\section{Towards a Mobility Paradigm}

The ABCD typology is still used in market research. However, in the second Post War years it began to be challenged, or at least discussed. Many market researchers and academics now argued that it no longer provided an adequate representation of consumer practice (if it ever had). Indeed, as early as 1949, W. Lloyd Warner, at the influential Chicago research company Social Research Incorporated (SRI) argued that "advertising agencies and their clients often waste their money" because of their ignorance of the actual make-up of class cultures. This was particularly true for the lower middle class which, according to Warner, was now undergoing substantial transformations (Warner, 1949: 30).

Indeed a number of developments made marketers question, or seek to go beyond the simple link between income and what Bourdieu (1984) would latter call class habitus. Firstly, American consumer culture was transformed in the post-War years. Rising standards of living, suburbanization, new materials like plastic, new design, new objects, television sets and domestic appliances and new institutions of consumption like the shopping mall all radically altered the material culture of middle class life. Many consumer researchers, like Warner and his colleagues at SRI, were influenced by contemporary sociological talk of 'mass society' and 'other direction', and argued that geographically rooted, communitarian taste and consumption patterns had begun to matter less than before. In short, American consumer behaviour seemed less determined by class-specific taste cultures.

Secondly, television brought about a thorough transformation of the media environment, surpassing the press as the main channel for advertising investments by the early 1960s (Turow, 1997). As the sponsorship model was abandoned for the 'scatter plan', in which advertising time on television was sold in the now familiar spot format, the medium generated an increasing pressure for audience segmentation, and hence more detailed research. A similar pressure came from the production side, as corporations were anxious to discover new market niches to exploit.

Thirdly, the new consumption and media environment was actively appropriated by consumers and goods were deployed in new ways to generate new patterns of consumption and styles of life. Youth were particularly active in this, producing a range of new youth cultures from the mid 1950s and on. But adult middle class consumers also did their share, in part borrowing from 
youth culture, in part transforming their own forms of demeanour and self-presentation. Hence, the 1960s saw the emergence of the 'Playboy', the 'New (emancipated) Housewife', and later 'The Single Girl': adult middle class styles that built chiefly around practices of consumption. During the 1970s this development would continue as new consumer goods, and in particular affordable fashion clothing further encouraged the performance of style and demeanour through consumption.

Finally, the market research sector itself boomed: The market research community grew all through the 1950s, and in 1963 the turnover of the research business was 10 times (in current dollars) that of thirty years before. The expansion of the research community also made the social scientist a common figure in marketing circles, and introduced social science terminology into marketing and advertising jargon (Bogart, 1963). The result was a pressure to generate more detailed and deeper descriptions of consumer behaviour and a growing suspicion towards the 'natural' centrality of the ABCD system. As Daniel Yankelovich, who later founded the successful Yankelovich Monitor in the 1970s (see below) wrote in 1964, "We should discard the notion that demographics is the best segmentation technique" (Yankelovich, 1964: 6).

The first significant break with the $\mathrm{ABCD}$ typology and the containment paradigm that it represented was motivation research (MR). Pioneered by Pierre Martineau (1957) and Ernest Dichter (1960), MR was a commercial adaptation of Freudian psychology that suggested that the real sources of consumer decisions lay in the hidden depths of their unconscious. By means of in-depth interviews, motivation researchers thus tried to reveal such hidden or unconscious real motives behind consumer decisions, and transform them into new market niches and advertising arguments. While established market researchers were extremely critical of the Motivation researchers' often sloppy methodology (Politz, 1956 - often Dichter's writings, as well as his research reports were rambling summaries of his own impressions), their fresh angle and the new information that the method provided showed commercially successful (Arvidsson, forthcoming). In addition, motivation research provided a perhaps unconscious, but important theoretical move away from the containment paradigm. Previously it had been thought that tastes and consumer patterns were an effect of the social and or cultural environment, and that consumers were hence determined by their surroundings. Motivation researchers however looked for and found needs and desires that were independent of, indeed often in opposition to that environment. Theoretically, motivation research thus contributed to de-linking consumers and their preferences from structural determination. Also, motivation research concentrated on the intimate or emotional relations that people had to goods. This contributed to generating a different picture of the relations between consumers and the goods they were surrounded with. Previously it had been thought that consumers bought and desired certain kinds of goods because their identity (or 'personality', to use the term in vogue at the time) was in a particular way. Now it became possible to think consumer identity as an effect of purchase patterns. As Sydney Levy (also of SRI) would write in an influential article on 'Symbolism and Life Style', "a consumer's personality can be seen as the peculiar total of the products he consumes" (Levy, 1964: 149).

The real shift towards an attention to consumer mobility came with psychographics. This method grew out of the dynamics that Motivation Research had initiated (Demby, 1974) Motivation 
research had opened up the possibility of viewing consumer subjectivity as (at least relatively) autonomous in relation to social structure and thus potentially mobile. At the same time MR was not methodologically capable of supplying valid and reliable information. Such methodological innovations came out of the work of SRI. Like Paul Lazarsfeld's Bureau of Social Research, SRI was a place where market researchers and sociologists interacted. The methodological tools it developed were employed in the emerging field of sociological studies of class, like as W. Lloyd Warner's Yankee City study as well as in market research. Both sociologists and market researchers shared an interest in reliable quantitative instruments that could provide a picture of what was understood to be a changing American class landscape.

In particular it became imperative to understand the culture of the 'classless' middle classes, the 'White Collars' as C. Wright Mills would later describe them, who were understood to be delinked from traditional ethnic or geographically rooted communities and appeared to form a kind of free floating mysterious entity (Mills, 1953; Whyte, 1955). In 1959 SRI sociologists Lee Rainwater, Richard Coleman and Gerald Handel published what has become know as the first life style study, The Workingman's Wife: Her Personality World and Life Style (Rainwater et $a l ., 1959)$. The study aimed to investigate empirically what advertisers hitherto had taken for granted: the cultural universe of their main advertising object: the Middle Majority Housewife. Rainwater and his colleagues combined demographic data similar to that or the old ABCD categories (they called it 'Index of Urban status') with Thematic Appreciation Tests borrowed from consumer psychology and in-depth interviews borrowed from motivation research. The study generated an in-depth descriptive picture of the everyday life of the Housewives, including information on their psychological attitudes and relations to consumer goods. Early studies like this produced detailed pictures of consumer cultures that were however, still coupled to a particular class position.

During the 1960s however, the variables used by Rainwater and his colleagues were developed into what became known as 'psychographic' variables usually encompassing the fields of 'Attitudes, Opinions and Interests' (Wells and Tigert, 1971; Demby, 1974). At the same time, advances in computer technology made it possible to employ a wide range of variables, 300 was not uncommon, and then use factor analysis to produce a number of variable clusters, to be represented theoretically as 'life styles' (Sheth, 1970; Digg, 1966). The Methodological procedure was thus very different from what had been the case in the ABCD system. There, consumers had been segmented according to one variable (or one series of variables) denoting class position. Now, segments were no longer defined a priori, but rather deduced from the rich data material generated by extensive questioners. This meant that the overall picture that was generated was no longer a priori determined by class. Also, the number of variables relating directly to consumption, such as product, brand or media choice tended to increase during the 1970 s as the lifestyle survey became standard marketing practice through the impact of successful services like Daniel Yankelovich's 'Yankelovich Monitor', founded in 1971, and later Arnold Mitchell and Stanford Research institute's VALS, which began officially in 1978.

The inductive approach of psychographics meant that consumers were no longer depicted as structured according to some over-riding principle. It also meant that the particular segments generated could change over time. As William D Wells recognized in his foreword to the 
American Marketing Association's 1974 volume on 'Lifestyle and Psychographics', this dynamic approach had developed as a response to a social environment that was perceived to be increasingly dynamic and marked by "rapidly changing values" (Wells, 1974: v; cf. Rathnell, 1964). It was to prove successful in the following decade as a new middle class, Bourdieu's "new petite bourgeoisie" (1984: 311) appropriated the new possibilities offered by a richer consumption and media environment to continuously produce new styles and fashions as well as identities and solidarities (cf. Touraine, 1973). To put it in the words of an advertising professional writing at mid century (Ruth Ziff, head of the Benton and Bowles' research department):

We are living in an era of pluralism, non-conformity and rapid change. Racial groups are seeking a new identity and proposing separation rather than assimilation. Social mores have changed rapidly. The women's movement is positing changes that may affect our basic family structure. Styles of living and dress are indeed varied. Consumerism has become a major force. These changes make more hazardous than ever reliance on our own pre-conceptions or on data on the consumer that is scanty or outmoded. This then is another reason for turning to psychographics.

(Ziff, 1974: 139)

\section{Mobility Established.}

Psychographics developed as a technique able to deal with increasingly mutable consumer practices that threatened to overflow the boundaries of the old ABCD typology. Also, it produced a much more far-reaching picture of consumers than what had been available before. Indeed, with psychographics the mobile agency of consumers, their production of new symbolic and social relations through their deployment of consumer goods could be valorized. Previously this mobility had been seen as problem, a complexity to be contained and reduced. Now, such 'life factors': changing and diverse consumer practices beyond pre-established notions of the ABCD typology, could become "the most important factors influencing and shaping economic activity" (Lazer, 1964: 132). This opening up of life itself as a source of productive diversity was the real innovation of psychographics.

This principle was what drove the development of the kinds of 'single source' information services described in the introduction, as well as techniques like the bar-code scan or internet tracking software in the 1980s and 1990s. Tracking life as a generic, mobile productive power (rather than the particular life form of a socially anchored group) responded to what had become established as the new knowledge interest of marketing. During the 1980s the growth and integration of the media industries produced a situation where classic distinctions like that between media message and advertising, or for that matter public or private were increasingly blurred (Abercrombie and Longhurst, 1998; Janson, 2001). Consumers began to appear as fragmented, nomadic individuals, moving around in a media saturated lifeworld constantly on the look for ways to constitute themselves as subjects. Generation X (or latter Generation Y), much debated by marketers and advertisers in the early 1990s, offered a theoretical embodiment of 
this new kind of consumer subjectivity. 'X'ers' had grown up with, and were marked by the virtually complete media-saturation of everyday life. They had become accustomed to the increasingly diversified fare of network television in the 1970s and to cable and VCR in the 1980s. As children, they had lived the disintegration of the nuclear family through the expansion of media choices and the proliferation of multi-set households. For them watching television was a solitary activity rather than a family ritual. Media, and in particular television, made up their main resource for knowing about themselves and the world. Consequently they were much more 'media literate' than their parents and skilled in art of dodging or evading advertising through 'zapping' or 'zipping' (Ritchie, 1995). While Generation X consumers were difficult to persuade or seduce, their experience of growing up in a fluid and multifaceted media universe also made them existentially insecure. It was thought that Generation X consumer were on the look for discourses and consumer goods that could function as a kind of medium for their own nomadic self-construction.

During the second half of the 1990s this kind of subjectivity was generalized as a representation of the 'post-modern' consumer in general (Holt, 2002; Firat and Venkatesh, 1995). At the same time, marketing went through what has retrospectively been called the branding revolution. Beginning with the proliferation of Customer Relations Management in the 1980s (Turow, 1997) brands began to be understood less as 'symbolic extensions of products' (cf. Gardner and Levy, 1955) and more as virtual communities constructed in media-space (Arvidsson, forthcoming; Lury, nd.). Brand value was increasingly understood to derive not so much from the product itself as from the particular experience or emotion that resulted from the inter-textual links that brand managers constructed around the product (Shields, 2003; Lash, 2002). Branding came to mean the practice of constructing temporary crystallizations of a consumer demand that was understood to be essentially fluid and mobile. Inductive cluster analysis supplied the necessary knowledge for this practice.

\section{Conc lusion: A Political Economy of Shadows.}

Market research, Paul du Gay (1996: 90) claims, aims at capturing the 'Real'; instead it produces 'Reality'. The complexity of life is reduced to abstract information that permits the construction of a programmed, mediated Reality of tastes, behaviours, values and lately experiences. Such a programming of consumption has been the scope of marketing and market research from the very beginning. Modern marketing was to consumption what scientific management was to production. Both were part of a capitalist 'control revolution' driven by the perceived 'complexity' of a potentially unruly or deviant workforce (cf. Beniger, 1986). Market research emerged as a disciplinary practice that aimed at containing this complexity in certain pre-established categories.

But, beginning in the 1950s it evolved into a paradigm of 'control' directed rather at the surveillance of an increasingly mobile consumer and at valorizing the plurality of information traces left by his/her movement in media and commodity space (cf. Deleuze, 1992). In marketing this shift roughly corresponded to the emergence of branding. The disciplinary paradigm was connected to the construction of a programmed life, a 'Reality', centred on particular consumer 
groups or personalities. Like in the case of the Middle Majority Housewife, this Reality was programmed in virtually all of its expressions; a whole life style was supplied. The control paradigm instead links to the construction of a more local and fragmented Reality built around brands, which mark off highly particular slices of life and that tend to contain partially automated elements. Sometimes this automation is technological: at Match.com, the search engine 'Venus' finds suitable dating partners for you, at Amazon.com, the search engine 'Eyes' anticipates your tastes and preferences. Usually it is cultural, the logo, the brand identity or the branded space (like Starbucks) anticipates certain kinds of behaviour and attitudes (Lury, 1999). Such branded realities also tend to be dynamic and interactive. Brands 'breath with the market' and change as information on consumers change (McDonalds docet!; Marazzi, 2002). Like the Reality show differs form the Soap opera, post-modern branded commercial reality differs form its predecessor: it is local, specific, dynamic and interactive.

The control paradigm thus permits a tighter and more efficient surveillance that makes use of consumer mobility rather than discarding it as complexity. This ability to follow the consumer around has been greatly strengthened by new technologies: software for data mining, barcode scans, internet tracking devices, and lately location based information from mobile phones. But I would suggest that the paradigm shift itself should not be understood as the simple outcome of new technology. Rather it has come about as part of a transformation of the relations of production within which these new technologies were employed. As Tessa Morris Suzuki (1984) suggested in an early essay, the automation of production through robots and information technology tends to shift the source of surplus value from the material to the immaterial. If the production of material objects comes to employ decreasing amounts of labour, the source of value becomes the production of innovations and new ideas, where labour is more difficult to replace.

Now, this argument can be expanded to argue that the key scarce resources of the information economy are immaterial use values like, ideas, design, 'content' or innovations (Preston, 2000; Todreas, 1999). This new situation has changed the role of marketing and market research. No longer strictly about containing complexity, marketing is becoming a practice in which the socialized production of ideas, innovations and 'content' is appropriated and valorized. In this sense, ubiquitous information gathering aims at appropriating the communicative action of life in all its walks as a source of immaterial 'content' that can contribute to the value of the brand 7 . While market research has so far mainly been able to track mobility in media-space, new technologies are extending its reach. Soon we will see sophisticated surveillance systems that capture the productivity of life in its physical and temporal dimensions as well.

I believe that the way to a critical understanding of this situation goes through a re-reading of Marx (and in particular the Grundrisse). Information capitalism can be said to be marked by what Marx called the real subsumtion of labour under capital, that is the inclusion of life in all its walks within the capitalist valorization process, and the subsequent disappearance of an outside

\footnotetext{
${ }^{7}$ Hence the popularity of 'cool-hunting' and ethnographic market research: 'cool' has to be quickly converted into brand value. Smartgirl Intenette is devoted to this kind of qualitative market research on the internet: http://www.smartgirl.org
} 
(community, life-world, privacy) from which a meaningful dialectic can depart. Life and capital are no longer distinct, or as Antonio Negri (1995: 152) puts it:

What is the form of value of the mode of production which is called 'real subsumption'? It is a form in which there is an immediate translatability between social forces of production and the relations of production themselves. In other words, the mode of production has become so flexible that it can be effectively confused with the movements of the productive forces; that is, confused with the movements of all the subjects who participate in production.

Life in all its walks is constituted as productive labour. The tools with which this life is lived, technologies, objects and increasingly, immaterial use values like brands are a form of ubiquitous 'dead labour' or capital. The extraction of surplus value in information capitalism entails the transformation of 'productive life' into 'dead values', like brands or 'content'. This is the main function of the ubiquitous surveillance of the panoptic sort. But this 'branding of life' also tends to lead to its automation. Branded life is programmed life. So far such programming techniques have been mostly cultural, but we are seeing the emergence of a revolution in the technological programming of life: ubiquitous computing, mobile internet, communicating domestic appliances all promise to render a series of reproductive and communicative tasks automatic (like buying groceries or finding a friend or lover). But, at least from a Marxist point of view, automatic processes do not produce value (cf. Caffentzis, 1997). Here stands the main contradiction of information capitalism. The process of automation that it sets in motion, and that has been greatly enhanced by information and communication technologies, tends to undermine the extraction of surplus value on which it builds.

Humanist critical thought tends to problematize the invasion of technology in everyday life and voice concerns over surveillance and the threat to privacy that it poses. A Marxist approach offers a different (if not incompatible) perspective: The growing surveillance and automation of life here appears as part of a contradiction that points towards a deep crisis in informational capitalism. As Marx wrote on machinery in the Grundrisse: "As soon as labour in the direct form has ceased to be the great well-spring of wealth, labour time ceases and must cease to be its measure, and hence exchange value must cease to be the measure of use value" (Marx, 1973[1939]: 705). If capital reaches its goal of eliminating labour, complexity, disturbance from its valorization process it also ends up undermining its own existence. What this contradiction might lead to remains an open question. But the idea that the inclusion of life within capital through its automation and surveillance entails both the triumph and the end of capitalism is worth considering for a critical theory of information and communication technologies.

\section{References}

Arvidsson, A. (forthcoming) The Labour of Consumption: Brands and the Subsumtion of Consumer Agency, Journal of Consumer Culture. 
Arvidsson, A. (under review) The 'Cultural Turn' in Marketing: Ernest Dichter and the Emotional Turn in Consumer Culture.

Arvidsson, A. (2003) Marketing Modernity: Italian Advertising from Fascism to the Postmodern, London: Routledge.

Bartels, R. (1976) A History of Marketing Thought, Columbus OH: Grind.

Beale, M. (1991) Advertising and the Politics of Public Persuasion in France, 1900-33, Unpublished Ph.D. dissertation, Department of History, University of California at Berkeley.

Beniger, J.R. (1986) The Control Revolution: Technological and Economic Origins of the Information Society, Cambridge Mass: Harvard University Press.

Beville, H.M. (1940) The ABCD's of Radio Audiences, Public Opinion Quarterly, June: 195206.

Bogart, L. (1963) Inside Market Research, Public Opinion Quarterly, 27(4): 562-577.

Bogart, L. (1987) Review: P. Bourdieu, 'Distinction', Public Opinion Quarterly, 51(1): 131134.

Bourdieu, P. (1984) Distinction, London: Routledge.

Bowlby, R. (1985) Just Looking: Consumer Culture in Dreisin, Gissing and Zola, London; Methuen.

Boyne, R. (2000) Post Panopticism, Economy and Society, 28(3): 285-307.

Caffentzis, G. (1997) Why Machines Cannot Create Value; or, Marx' Theory of Machines. In J. Davis, T. Hirschl, and M. Stack (eds.) Cutting Edge. Technology, Information Capitalism and Social Revolution, London; Verso.

Calkins, E. and R. Holden (1905) Modern Advertising, New York; Appelton \& co.

Camp, J.L. (1999) Web security and privacy: An American perspective, The Information Society, 15: 249-256.

Campbell, J.E. and M. Carlson (2002) Panopticon.com: Online surveillance and the commodification of privacy, Journal of Broadcasting and Electronic Media, 46(4): 586-606.

Cherington, P.T. (1924) Statistics in Market Research, Annals of the American Academy of Political and Social Science, 115: 130-35. 
Chessel, M. (1995) L'émergence de la publicité. Publicitaires, annonceurs et affichistes dans la France de l'entre-deux-guerres, Unpublished Ph.D. dissertation, Department of History and Civilisation, European University Institute, Fiesole, Italy.

Converse, J.M. (1987) Survey Research in the United States, its Roots and Emergence, 1890-1960, Berkeley; University of California Press.

Cova, B. (1997) Community and consumption: Towards a Theory of the Linking Value of Products and Services, European Journal of Marketing 31(3): 297-316

Davenport, T and J.C. Beck (2000) The Attention Economy, Cambridge (MA): Harvard Business School Press.

Deleuze, G. (1992) Postscript on the Societies of Control, October 59: 3-7.

Demby, E. (1974) Psychographics, from whence it came. In D.W. Wells (ed.) Life Style and Psychographics, Chicago: American Marketing Association.

Dichter, E. (1960) The Strategy of Desire, New York: Boardman \& Co.

Digg A.T. (1966) Lintas in Computerland, Admap, December: 35-36.

du Gay, P. (1996) Consumption and Identity at Work, London: Sage.

Elmer, G. (2003) A diagram of panoptic surveillance, New Media \& Society, 5(2): 231-247.

Export Advertiser (1930) Advertisement: 'Cinelandia', July, p.25.

Ewen, S. (1976) Captains of Consciousness, New York, McGraw-Hill.

Firat, F.A. and A. Venkatesh, (1995) Liberatory Postmodernism and the Reenchantment of Consumption, Journal of Consumer Research, 22: 239-267.

Foucault, M. (1977) Discipline and Punish, New York: Vintage.

Fox, S. (1984) The Mirror Makers: A History of American Advertising and its Creators, New York: William Morrow \& co.

Gabriel, Y and T. Lang, (1995) The Unmanageable Consumer. Contemporary Consumption and its Fragmentation, London: Sage.

Gandy, O. (1993) The Panoptic Sort: A Political Economy of Personal Information, Boulder: Westview Press. 
Gardner, B. and S. Levy (1955) The product and the brand, Harvard Business Review, March-April, pp. 33-39.

Haggerty, K.D. and R.V. Ericson (2000) The surveillant assemblage, British Journal of Sociology, 51(4): 605-622.

Harvey, D. (1990) The Condition of Postmodernity, Oxford: Blackwell.

Holt, D.B. (2002) Why do brands cause trouble? A dialectical theory of consumer culture and branding, Journal of Consumer Research, 29: 70-90.

James, E.P.H. (1937) The Development of Research in Broadcast Advertising, The Journal of Marketing, 2: 141-145.

Janson, A. (2001) The Mediatization of Consumption. Towards and Analytical Framework of Image Culture, Journal of Consumer Culture, 2(1): 5-36.

Jhally, S. (1987) The Codes of Advertising, London: Routledge.

Jones, B.D. and D.D. Monieson (1990) Early Development of the Philosophy of Marketing Thought, Journal of Marketing, 54: 102-113.

Lash, S. (2002) Critique of Information, London: Sage.

Lazarsfeld, P. (1938) The Panel as a New Tool for Measuring Opinion, Public Opinion Quarterly, 2(4): 596-612.

Lazer W. (1964) Life Style Concepts and Marketing. In S.A. Greyser (ed.) Toward Scientific Marketing: Proceedings of the Winter Conference of the American marketing Association, 27-28 December 1963, Boston / Chicago: American Marketing Association.

Levy, S. (1964) Symbolism and Life Style. In S.A. Greyser (ed.) Toward Scientific Marketing: Proceedings of the Winter Conference of the American marketing Association, 27-28 December 1963, Boston / Chicago: American Marketing Association.

Lockley, L. (1950) Notes on the History of Marketing Research, The Journal of Marketing, 14: 733-36.

Lury, C. (2002) Marking Time with Nike: The Illusion of the Durable, Public Culture, 11(3): 499-526.

Lury, C. (nd.) The Objectivity of the Brand: Marketing Law and Sociology. Unpublished Manuscript. 
Maffesoli, M. (1996) The Time of the Tribes: The Decline of Individualism in Modern Society, London: Sage.

Marazzi, C. (2002) Capitale e linguaggio, Rome: DeriveApprodi.

Martineau, P. (1957) Motivation in Advertising, New York: McGraw-Hill.

Meyrowitz, J. (1985) No Sense of Place, New York: Oxford University Press.

Miller, M. (1981) The Bon Marché: Bourgeois Culture and the Department Store 18691920, Princeton NJ: Princeton University Press.

Mills, C.W. (1953) White Collar, Oxford: Oxford University Press.

Miranda, J. (1998) The performance of consumption and production, Social Text, 54(10): 2561.

Mitchell, A. (1984) Nine American Lifestyles, New York: Warner Books.

Morris-Suzuki, T. (1984) Robots and Capitalism, New Left Review, 147:

Negri, A. (1996) Twenty Theses on Marx. In S. Makdisi, C. Casarino and R. Karl (eds.) Marxism beyond Marxism, London: Routledge.

Ohmann, R. (1996) Selling Culture: Magazines, Markets and Class at the Turn of the Century, London: Verso.

Osgerby, B. (2001) Playboys in Paradise, Masculinity, Youth and Leisure Style in Modern America, Oxford: Berg.

Palladino, G. (1996) Teenagers: An American History, New York; Basic Books.

Politz, A. (1956) Motivation research from a research perspective, Public Opinion Quarterly, 20(4): 663-673.

Preston, R. (2000) Content is King, New Media \& Society, 2(3): 253-267.

Rainwater, L., R. Coleman, and G. Handel (1959) The Workingman's Wife: Her Personality, World and Life Style, New York: Oceana.

Rathnell, J.M. (1964) Life Style Influences and Market Segmentation: An introduction. In S.A. Greyser (ed.) Toward Scientific Marketing: Proceedings of the Winter Conference of the American marketing Association, 27-28 December 1963, Boston / Chicago: American Marketing Association. 
Ritchie, K. (1995) Marketing to Generation X, New York: Lexington Books.

Scanlon, P. (1995) Inarticulate Longings: The Ladies Home Journal, Gender and the Promise of Consumer Culture, London: Routledge.

Sennett, R. (1977) The Fall of Public Man, Cambridge: Cambridge University Press.

Sheth, J. (1970) Multivariate analysis in marketing, Journal of Advertising Research, 10(1): $110-125$.

Shields, R. (2003) The Virtual, London: Routledge.

Skeggs, B. (2003) Valuing Class, London: Routledge.

Simmel, G. (1896[2000]) Das Geld in der Moderneren Kultur, Zeitschrift des Oberschlesischen Berg un Huttenmennischen Vereins, 35: 319-24, trans. 'Money in Modern Culture', in D. Frisby and M. Featherstone (eds.) Simmel on Culture, London: Sage.

Stearns, P. (2001) Consumerism in World History, London: Routledge.

Smythe, D. (1981) Dependency Road, Norwood: Ablex.

Todreas, T. (1999) Value Creation and Branding in Television's Digital Age, Westport CT: Quorum Books.

Touraine, A. (1973) La production de la societé, Paris: Éditons du Seuil.

Turow, J. (1997) Breaking Up America: Advertisers and the New Media World, Chicago: University of Chicago Press.

Urry, J. (2000) Sociology beyond Societies, London: Routledge.

Warner, W.L. (1949) Social Class in America, New York: Harper.

Weiss, M.J. (1989) The Clustering of America, New York: Harper \& Row.

Wells, D.W. (1974) Foreword. In D.W. Wells (ed.) Life Style and Psychographics, Chicago: American Marketing Association.

Wells, D.W. (1975) Psychographics: A Critical Review, Journal of Marketing Research, XII: 196-213.

Wells, W. and D. Tigert (1971) Activities, Interests and Opinions, Journal of Advertising Research, 11: 27-35. 
Whyte, W.H. (1955) The Consumer in the New Suburbia. In L.H. Clark (ed.) Consumer Behaviour: The Dynamics of Consumer Reaction, New York; NYU Press.

Yankelovich, D. (1964) New Criteria for Market Segmentation, Harvard Business Review, Spring: 83-90.

Ziff, R. (1974) The Role of Psychographics in the Development of Advertising Strategy and Copy. In D.W. Wells (ed.) Life Style and Psychographics, Chicago: American Marketing Association. 